\title{
THE PERCEPTIONS OF THE CITIZENS OF REPUBLIC OF MACEDONIA ABOUT THE WORK OF THE POLICE
}

\author{
Cane Mojanoski, PhD \\ Faculty of security-Skopje, University 'St.Kliment Ohridski'-Bitola \\ E-mail: cmojanoski@fb.uklo.edu.mk
}

\begin{abstract}
In this paper are analyzed the research results of several battery questions for the assessments on the work of the police from 2008 to 2017. It is about field researches, conducted in all mountain regions in the Republic of Macedonia, among 30 and 40 municipalities. The number of the correspondents ranged from 1032 in 2017 to 1440 in 2011. (By years that is: in 20081163 correspondents, in 20091318 correspondents, in 20101309 correspondents, in 20111404 correspondents, in 2012 1240 correspondents, in 20131138 correspondents, in 20141167 correspondents, in 20151016 correspondents, in 20161044 correspondents and in 20171032 correspondents. The sample is structured as multi-staged and it belongs to the group of intentional samples. The paper through longitudinal approach shows the variations of the citizens' perceptions about the police, its relation with the citizens and the realization of the functions they perform in the society. Some of the results indicate that among the citizens' perceptions dominate the thinking that the police are instrumentalized by the governing party. Namely, more than one third or approximately $36,86 \%$ of the correspondents had that opinion. Also the proportions of the correspondents with that perception vary from $31,71 \%$ in 2013 to $41,09 \%$ in 2016 . In this indicator framework belong the answers about the attitude of the police in the process of exercising the right to equality. Checked through the answer about selectivity in the police actions. The citizens' perceptions from 2009 to 2017 in average $38,43 \%$ had a positive attitude, and $61.57 \%$ negative attitude.
\end{abstract}


The research results offer a certain indicator framework about the image of the police and their actions in the decade development which is a subject of interest of the researches.

Key categories: police, public, confidentiality, image of the police, citizens

\section{Introduction}

The police and the police organization are subject of research for many disciplines and sciences. The modern sociological and politico logical approaches toward the police are focused on the fact that it is a distinct entity and it has its own tasks and authorities, organizational structure, staff, means and specifications that on one or another way are its diferentia specifica. By its position and functions it has an important role in the society and the exercise of those functions makes it in constant interaction with the society. If we have on mind the fact that the surrounding of the police system, grosso modo, consists of the global society in which the central part belongs to the most organized part of it- the state. More and more louder are the attitudes that "the society shapes the function of the police, or that function in bottom line comes from the needs, the conditions and the relations in a certain society, as well as that once confirmed content of the police function changes along with the changes in the society" (Milosavljević, 1992).

Today is almost impossible to be built a consensus about the term police and about the scope of the use of that term. It is about many approaches, concepts and definitions, or one multi-defining situation. For the analytic needs of the paper the police is defined as :'organizational and functional term, formal and material, strategic and dynamic, the police as a state body and public service' (Milosavljević, 1992).The poitica science observes the police as a political rarity that has a monopoly over the legitimate physical violence realized by the help of the police as an executive body. Formaly speaking the police is based on the authorities, the organizational forms, the authority in the society, it is an organ that by prescribed by law security situations prevents all the behaviours that can lead to unwanted consequences.

Contrary to the formal, the material approach prioritizes the fundamental goal of the police as keeping the internal security; it is about a legitimate function that 
serves as a practical operation of the brought regulatory rules in the society. It is considered to be an integral part of the society which by adjusting to the modern and the democratic changes is especially cautious in the treatment of individual conflicting situations with the purpose of construction of optimum interactive relationships and gaining confidence by the citizens. The police also can be determined as a state body, as a public service, which depends on the shaping of the organization of the society. That is why the police is defined as complex, specific and dynamic executive body of the government, which according to the legal powers is in charge for keeping the internal security of the society, through legitimate use of the means for force accompanied by the ethical principles of the duties and the responsibilities (Masleša, 1999), (Masleša, 2008).

The term police in the broadest sense means a system of separate bodies of the internal management which in the realization of its tasks is equiped with institutional pressures. In an objective sense the police has protective function toward the public order and menatility that allows it to realize its protective function. In functional sense mainly it is accepted the dision of administrative and criminal police (Modly, Korajlić, 2002,p. 455).

The interaction is reciprocal (Bayley, 2006, p. 159). It means that the police system manifests positive (or negative) impulses and initiatives towards the environment. In the first case, the police is the factor that creates a positive environment, creates order and certainty in the environment, i.e. it is the factor that allows and progresses the prosperity of the society. Conversely, in the second case, the police manifests as hindrance of developing social trends. In certain cases, it can occur as a deterrent to the development of society, instrument of the party interests and instrument for the preservation of social relations. For this part of the functioning of the police system in the society there are numerous examples in the history.

Here we will remind that the interaction between the police system and the environment doesn't happen just on a level of the global society but also locally on a level of distinct segment of the society, connected to the execution of the regular police tasks. It's about acting in the environment which structurally and institutionally is a complex whole and has its marks. They can be of different nature, like: nationality, religion, age, gender, economic, political party or other structure. In that context belong the numerous and diverse organizations, institutions and social systems, which in one way or another are in constant interaction (Barsamian \& Čomski, 2004), (Habermas 


\section{Seccurity}

2012) (Milosavljević, 1992). Observed from the angle of the social structure can be concluded that the social environment toward the police reflects in numerous complex shapes, in contradictory requirements and conditions that require complex procedures and actions. Such complex and numerous events, conditions and forms established specific relations between the police system and the individual segments of the social environment. The specific relations of interaction manifest themselves as separate influences followed by different intensity, content and meaning. Given account to intensity, content and meaning of influences as especially important areas of interaction of the police system and the social environment can then be allocated a certain dominant and distinctive form of relationship as the relationship of the police and:

$>$ a) the citizens;

$>$ b) distinct social and ethnic groups;

$>\quad$ c) the media (Milosavljević, 1992).

The history knows numerous experiences about the relations between the police and the citizens. There were periods when the police had, so to say, limitless powers. Then ruled the attitude that everything which is good for the welfare and the safety of its subjects is allowed and that the interest of the state is above everything.Or it was about the uncontrolled use use of force and the reigning principle of advisability over the principle of legality. The social changes in the foreground have stressed the requirements for freedom of action and making the state intervention to what is necessary (Гаћиновић , 2012). Then it was developed the concept that the security should not rely on the police, but the citizens are the ones that have to organize their own safety and protection expressed through the emergence of self-help groups, night guards of citizens, the arms of the citizens for the protection of their own security, a broad notion of the right of self-defense and other experiences, which indicate that care is the property and duty of the citizens (Masleša, 2001).

But along with the development of the modern society and the emphasized role and the importance of the state, applied in the forms of the state intervention, affected the undertaking numerous tasks and the police function have transformed in institution that is the most organized and most efficient. In such circumstances has been emphasized the social function, which means that the police in the society has 


\section{Seccurity}

been organized for preventing disorder and violence in order to be set up control over the conflict between the weaker and the stronger. The strengthening of the state and the police contributes the citizen to be seen as a subject of the relations with the public administration and on that ground to enjoy certain rights. So the general political role of the citizen is getting changed. The citizen is an active subject in the political system, who decides through elections who is going to for a government and who is going to control the administration (Bayley, 1996).

Such social conditions contribute the relations between the police and the citizens to get new shapes and contents. The police, conceptually looking, orient toward the demands and the needs of the citizens, toward respecting of the freedoms and the rights and its readiness to promptly react to those requests (Bayley, 1996). The political function is complex. It basically covers the contents of preventing and managing conflicts, the application of regulations, especially those that one way or another mean restriction of certain individual freedoms and rights of citizens (Grabosky, 2009). Component parts of these contents are also the application of the physical coercion on behalf of the state against the entities that violate the law. Among the citizens there are such who consider themselves "prospects police" or have that been, and the officers for many are "bad co-news" and "visible reminder of the dark and repulsive side of the human behavior" (Milosavljević, 1992).

We should have on mind that the police have always been an epitome of powerful organization and the police officer of person with delegated right for arresting and even use of indirect force against the citizens (Crank, Murray, Irlbeck, \& Sundermeier, 2011). Of course, there are some misunderstandings especially when the police officers forget their true goal and the legal dimensions of its authorities. The manifested shape of this kind of behavior is the emphasized reliance on the strength and in practices every citizen to be seen as potential criminal. That creates practices of unequal usage of the law. The public is especially sensitive to the cases of unequal treatment by the police to certain categories of citizens, especially to the vulnerable categories (homeless, LGBT), sexual and other minorities, people with different political belonging etc. Here we come to two contradictions according to which the police organization sometimes more sometimes less successfully endeavors and acts as a closed system, conceal their weaknesses and does not address the courts to the public about its activities, especially those opinions which emphasize inadequate treatment and errors in its work. (Masleša, 1999) It is about the traditional model of police, 


\section{Seccurity}

according to which it is not trying to establish closer relations with the citizens and the public (Held \& McGrew, 2010). This attitude, as you can assume has a negative impact on the relations between the police and the citizens. These relations are generally satisfactory, sometimes solid. The perceived weaknesses of poor relations with the public are presented in the form of mutual mistrust, passive attitude of citizens toward crime events in their environment and failing to provide assistance to the police, then expressed criticism of the police, to manifestations of intolerance, open antagonism or to cases of conflict with the police.

The experiences show that in the whole functioning of the police, especially in its realization of the main tasks, can hardly be achieved more important success or be created efficiency in the acting if the police doesn't have respect, support, collaboration and help from the citizens. We should underline that the success of the police nowadays can't be measured only by the number of solved criminal acts and undertaken actions, but also by how positive are its relations with the citizens. (Maljević, Datzer, Muratbegović, \& Budimlić, 2006). That is particularly important to be stressed because in the divided societies, such as the Macedonian, it is crucial for the police to impose itself as a protector of the human rights, not as a government service or service of political and party nomenclature (Ideološki i politički konflikti (Osvrt na kulturu dijaloga), 2011).

The area of the relations of the police with the citizens has many mutually conditioned components. The most important are : '(1) the relation to the citizens as users of the services and subject with personal rights and freedoms (human relations), (2) the relation to the citizens as subjects of the social control and collaborators of the police in its work and (3) the relation to the citizens as factor of the public opinion (public relations)'(Milosavljević, 1992)

The research results that are subject of analysis refer to the attitude of the police toward the citizens as a factor of the public opinion, or how the citizens perceive the work of the police? Indirectly it should be given an answer to the question if and how the police manages to open itself to the citizens, or if the approach and the organization of the police has expected and most usually positive effect? Actually, it is about the contents that include the activities of the police that aim to ensure the public is adequately to accept their action, i.e. to contribute towards the building and maintenance of the desired opinion about the police in public. It means, the police in the public should enjoy the reputation, respect and trust, and its activity enjoys 
acceptance and approval. The realization of this goal is directly related to the question of the legitimacy of the police, i.e. with the positive attitude of the majority of the public towards the role and authority of the police. So, it should goal towards that the majority of the citizens to understand the role of the police and accept it as an important prerequisite for the personal and property safety, free life and work in the community and a factor for peace-building and common life in the society (Mirosavljević, 2006).

The main characteristic of the modern police working is the idea that the police and the citizens are working on achieving the common goals - safe and secure community lives. To affirm their successes and to strengthen the trust among the citizens, the police should constantly work on the approving by the public. A prerequisite for obtaining public support is the publicity in policing and fostering the communication and the mutual understanding between the police and the citizens.

\section{Methods and instruments}

About what is like the perception of the citizens about the police we will present the results of the survey conducted on the territory of Republic of Macedonia in the period 2008-2017. It is a field research, conducted in all mountain regions in the Republic of Macedonia, among 30 and 40 municipalities. The number of the correspondents ranged from 1032 in 2017 to 1440 in 2011. (By years that is: in 2008 1163 correspondents, in 20091318 correspondents, in 20101309 correspondents, in 20111404 correspondents, in 20121240 correspondents, in 20131138 correspondents, in 20141167 correspondents, in 20151016 correspondents, in 20161044 correspondents and in 20171032 correspondents. The sample is structured as multistaged and it belongs to the group of intentional samples. (Mojanoski, 2015). It is constructed by choosing municipalities in every mountain region that will later be a subject of the field activity. In every inhabited place was constructed an urban or rural core and was chosen the principle of moving on the right side. Every fifth family was visited in the individual places, or every 20th in the collective buildings. The choice of the interviewee is based on the principle the closest birthday of an adult person living at that address. The instrument according to the method of filling is a structured 
interview. Each researcher is keeping a diary (Mojanoski C. T., 2012). The survey was conducted every year in the period from January 8 to 20 .

The instrument is constructed in a form of socio-demographic survey with certain sets of battery questions of closed type with answers from the Likerts scale (from I don't agree at all to I fully agree and I cannot estimate), then battery of questions with dichotomy answers, questions with more choices and open questions. Subject of this paper will be the questions regarding the perceptions of the citizens about the work of the police and its attitude toward them.

\section{Results and discussion}

The debate is directed to the actualization of certain dimensions of the research results for the attitude of the police towards the citizens as a stakeholder in the public opinion, i.e. how the citizens perceive the work of the police? In the analysis the previously was defined the question associated with whether the respondents had contact with the police? The answers to this question are the indicator that creates the assumption or may reference the fact that the views expressed by individual questions can be based on the empirical experiences of the respondent or, they more or less are results of the notions of the social reality.

Figure 1 Have you had a contact with the police so far?

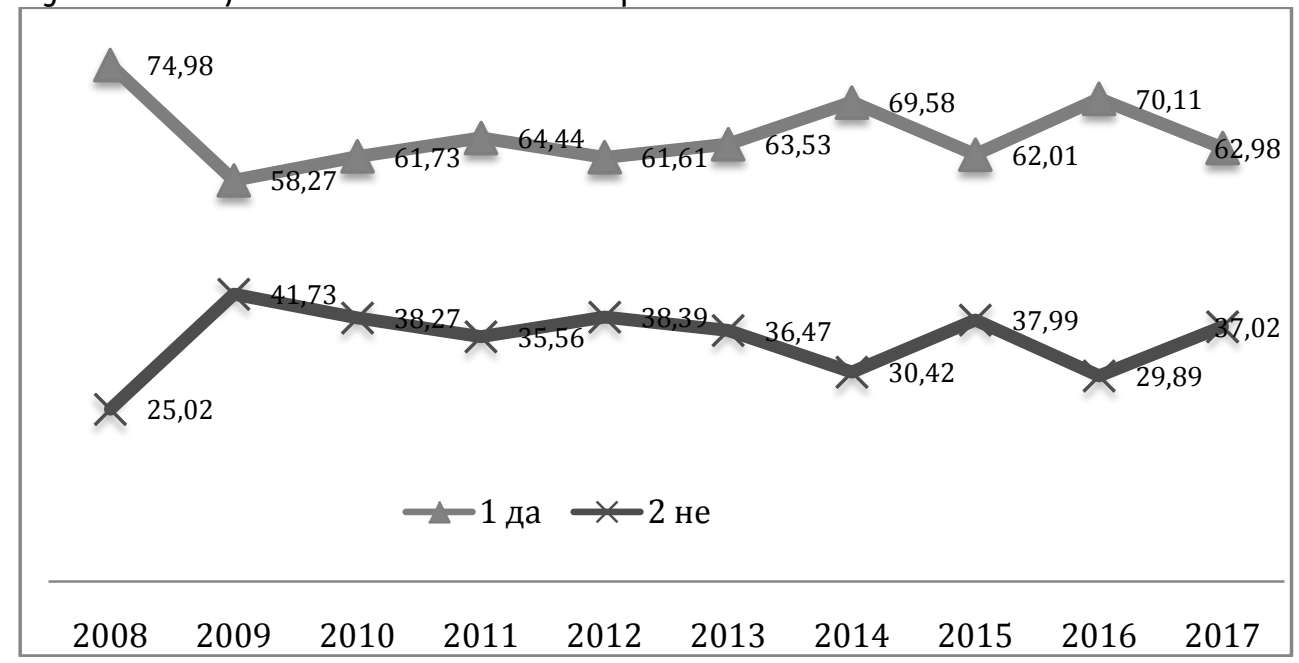




\section{Securiagues rity}

From the graphical view (Figure 1) can be seen that the respondents, or the citizens, that it moves within the framework of four fifths in 2008, to more than a half in 2009 . It is specific that $64,93 \%$ or almost two thirds of the respondents said that they had a contact with the police. The answer is consequence of the insufficient specifies of the question on one hand, but also that in the services of the police were found a considerable number of services associated with the issuance of personal, traffic and other documents that are necessary for unimpeded traffic of the individual in society.

We should also keep in mind that in this period was carried out a change of the personal documents, especially in 2008 and 2009, when a significant part of the citizens were directed towards the state authorities, in particular to the services, even though they organizationally belonged to other organs of the administration, they, because of the longstanding practice were linked with the bodies of internal affairs, which more or less was perceived as "police".

In the analysis we are not really interested in, whether and how the citizens are directed towards the Police station. The answers to these questions can be treated as indicators of how this form of organization and the police action is perceived as a structure that the citizen believes in and is willing to address to.

Figure 2 Have you in the past three months attended a Police Station?

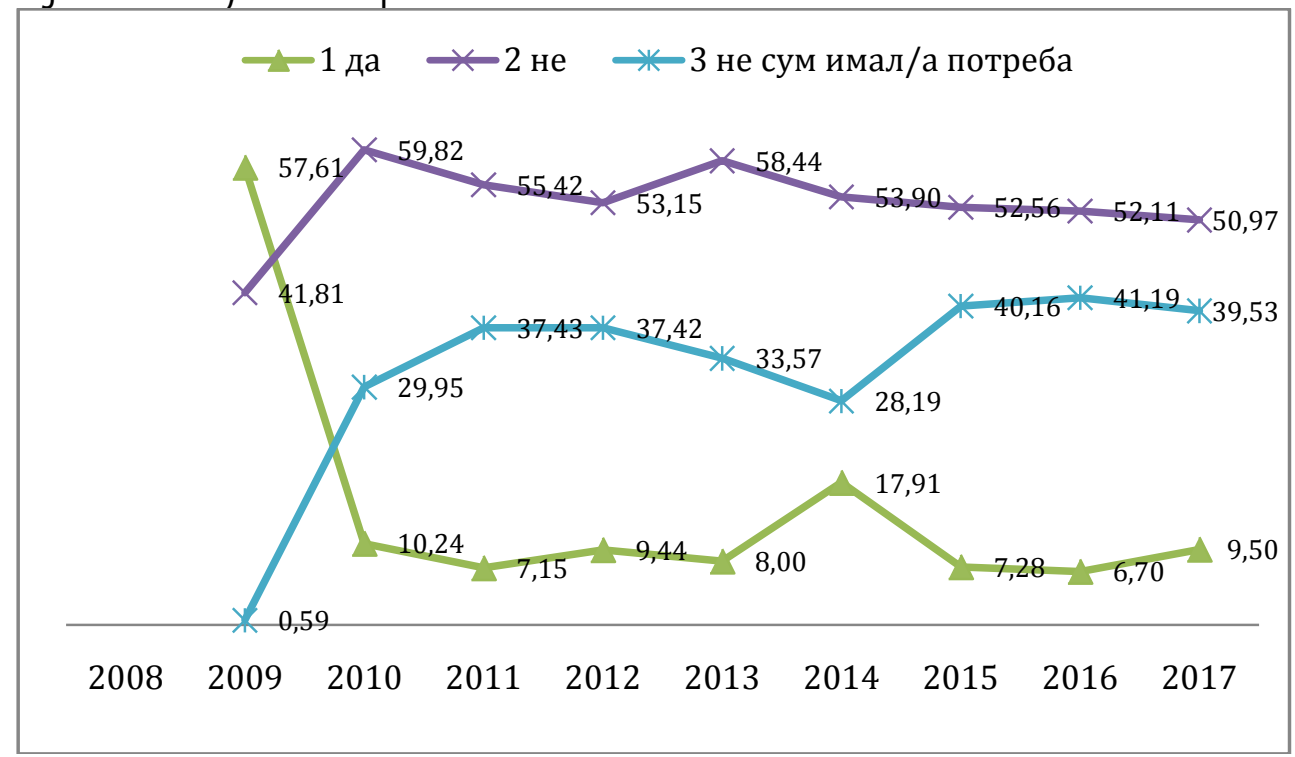




\section{Secururity}

This question has been included in the research since 2009 when it was done a revision and amendment of the gathering data instrument. From the graphical view it can be concluded that in 2009 a significant number of respondents had confirmative answer. Such a deviation of the answer in 2009 compared to the other can be a result of the need for getting a form of help or information about the way of solving question related to personal and other documents.

About the image of the police among the citizens the analysis will be based on several indicators. But first, please answer the question: whether the contact with the police contributes to change your attitude to the police?

Table $1_{\text {"1 }} 19$. Whether the contact with the police contributes to change your attitude to the police?

\begin{tabular}{lllllllllll}
\hline \hline & 2008 & 2009 & 2010 & 2011 & 2012 & 2013 & 2014 & 2015 & 2016 & 2017 \\
\hline yes & 52,39 & 50,79 & 35,40 & 38,50 & 37,52 & 45,52 & 43,26 & 38,40 & 34,29 & 32,56 \\
no & 47,61 & 49,21 & 64,60 & 61,50 & 62,48 & 54,48 & 56,74 & 61,60 & 65,71 & 67,44 \\
& 100,00 & 100,00 & 100,00 & 100,00 & 100,00 & 100,00 & 100,00 & 100,00 & 100,00 & 100,00
\end{tabular}

The affirmative answers to this question show that they are rating from $52,39 \%$ in 2008 to $32,56 \%$ in 2017 year. On what is based this position? The answer is more complex. In addition, we will mention a number of answers to the questions whose function is to offer indicatory framework for the building of the paragraph or the offering of one of the possible answers. We will observe that through the two options. The first that "the police serves exclusively to the governing party", and the second

"The police are unfairly criticized for the closeness with the ruling party".

Table 2 30.12. The police serves exclusively to the governing party

\begin{tabular}{lrrrrrrrrr}
\hline \hline & 2009 & \multicolumn{1}{c}{2010} & \multicolumn{1}{c}{2011} & \multicolumn{1}{c}{2012} & \multicolumn{1}{c}{2013} & \multicolumn{1}{c}{2014} & \multicolumn{1}{c}{2015} & \multicolumn{1}{c}{2016} & \multicolumn{1}{c}{2017} \\
\hline No & 63,46 & 61,41 & 63,26 & 62,45 & 68,29 & 63,68 & 63,68 & 58,91 & 63,08 \\
Yes & 36,54 & 38,59 & 36,74 & 37,55 & 31,71 & 36,32 & 36,32 & 41,09 & 36,92 \\
Total & 100,00 & 100,00 & 100,00 & 100,00 & 100,00 & 100,00 & 100,00 & 100,00 & 100,00 \\
\hline \hline
\end{tabular}

The answer to this question shows dynamic that goes from $31,71 \%$ in 2013 to $41,09 \%$ in 2016 . It is visible that more than one third or approximately $36,86 \%$ of the respondents yearly think that the police is instrument of the governing party. Does this 
type of attitude can be treated as an indicator of the politicization of the police? The answer will be seek through analysis of a different attitude that has a function of a controller of the previous. Namely, in the same research the citizens were asked to express their degree of agreement with the attitude that "the Police are unfairly criticized for the closeness with the ruling party". The answers of this question (which also are measured from 2009) are given in the following table.

Table 3 30.15.The police is unfairly criticized for its closenest with the governing party

\begin{tabular}{|c|c|c|c|c|c|c|c|c|c|}
\hline & 2009 & 2010 & 2011 & 2012 & 2013 & 2014 & 2015 & 2016 & 2017 \\
\hline $\begin{array}{l}1 \text { I don't } \\
\text { agree at all } \\
2 \text { I don't }\end{array}$ & 9,31 & 8,49 & 10,86 & 8,10 & 8,47 & 14,58 & 8,56 & 12,45 & 9,40 \\
\hline $\begin{array}{l}\text { agree } \\
3 \text { | can't }\end{array}$ & 24,89 & 24,10 & 25,12 & 26,80 & 26,38 & 27,19 & 27,07 & 27,49 & 27,91 \\
\hline rate & 40,46 & 40,78 & 37,37 & 38,62 & 36,01 & 27,62 & 42,42 & 34,29 & 39,24 \\
\hline $\begin{array}{l}4 \text { I agree } \\
5 \text { I fully }\end{array}$ & 18,93 & 20,89 & 19,49 & 20,24 & 22,73 & 20,75 & 17,03 & 19,16 & 17,54 \\
\hline agree & 6,41 & 5, & 7,17 & 6,23 & 6,42 & 9,86 & 4,92 & 6,61 & 5,91 \\
\hline Total & 100,00 & 100,00 & 100,00 & 100,00 & 100,00 & 100,00 & 100,00 & 100,00 & 100,00 \\
\hline
\end{tabular}

The distribution of the answers shows that in the past period approximately $26,23 \%$ of the respondents have agreed with the attitude that the police is unfairly criticized, 36,35 don't agree and 37,42\% have undefined attitude or they say that they can't rate it. The positive answers in Table 2 and the negative answers in Table 3 are almost identical.

To this indicatory framework we will add the answers of the question what is the attitude of the police in the realization of the right to equality. We will illustrate that claim through the answer about the selectivity as a characteristic. From the answers' distribution from 2009 to 2017 we can conclude that $38,43 \%$ of the respondents have positive and $61,57 \%$ negative attitude.

Table 4 30.13.The police arrests selectively

\begin{tabular}{lrrrrrrrrr}
\hline \hline & 2008 & 2009 & \multicolumn{1}{c}{2010} & \multicolumn{1}{c}{2011} & \multicolumn{1}{c}{2012} & \multicolumn{1}{c}{2013} & \multicolumn{1}{c}{2014} & \multicolumn{1}{c}{2015} & \multicolumn{2}{c}{2016} & \multicolumn{2}{c}{2017} \\
\hline No & 59,79 & 60,61 & 60,39 & 61,67 & 68,09 & 61,81 & 61,71 & 58,24 & 61,82 \\
Yes & 40,21 & 39,39 & 39,61 & 38,33 & 31,91 & 38,19 & 38,29 & 41,76 & 38,18 \\
Total & 100,00 & 100,00 & 100,00 & 100,00 & 100,00 & 100,00 & 100,00 & 100,00 & 100,00 \\
\hline \hline
\end{tabular}




\section{Seccurity}

If we look at the dynamic of the positive answers in 2010 it declines for $-2,04 \%$ in relation to 2009, in the next year it increases for $0,56 \%$, in 2011 declines for $-3,23 \%$ and during the next two years it keeps the tendency for 0,26\% and 9,06\%, and in 2017 that number declines to $-8,57 \%$ in relation to 2016 . The most elementary analysis indicates that in the notions of citizens on the work of the police, the impact have the events and the proceedings of the police, especially for certain events such as is for example the case with the events in the country after the events in the parliament during the adoption of the budget and the work and the removal of deputies from the hall. That event caused a particular media attention and was the subject of a serious and fierce partisan and media calculation, which more or less influenced the shaping of the awareness and attitudes towards the police and police work. Also here you need to have and incident cases of unequal access and speed in solving the problems connected with the events and individuals in the society. In this context, the illustrative are the data presented in the Table 5 .

Table 530.14 . The police arrests only those who are not close to the governing party

\begin{tabular}{lrrrrrrrrr}
\hline \hline & 2009 & \multicolumn{1}{c}{2010} & \multicolumn{1}{c}{2011} & \multicolumn{1}{c}{2012} & \multicolumn{1}{c}{2013} & \multicolumn{1}{c}{2014} & \multicolumn{1}{c}{2015} & \multicolumn{1}{c}{2016} & \multicolumn{1}{c}{2017} \\
\hline No & 66,18 & 65,49 & 70,40 & 71,88 & 74,11 & 69,45 & 73,23 & 68,97 & 68,70 \\
Yes & 33,82 & 34,51 & 29,60 & 28,12 & 25,89 & 30,55 & 26,77 & 31,03 & 31,30 \\
Total & 100,00 & 100,00 & 100,00 & 100,00 & 100,00 & 100,00 & 100,00 & 100,00 & 100,00 \\
\hline \hline
\end{tabular}

Namely, approximately $30,18 \%$ of the respondents in the past nine years had the attitude that the police arrests only those who are not close to the governing party, which along with the previous attitude that arrests selectively show difference of $8 \%$ approximately. The both data refer to the fact that during the police actions there is a certain number of acts and contents that are not sufficiently convincing and do not talk about the professional status and access to the police. Actually it comes to perceptions that more or less are under the pressure of the media presentation of events, but also insufficiently clear and transparent terms of police and law enforcement structures to the public. This is about perceptions that are complex of legal and moral obligations and responsibilities of the police with regard to the proper performance of its duties, respect for human dignity and respect for all citizens and their freedoms and rights.

Also, we need to have on mind that the attitude of the police toward the citizens is in complexed relations of the society and the struggle against the criminal 
and corruption, and the lack of more visible results from the citizens' tries to be partners in the care for the community. In that role the citizens can contribute to the security of the community and by that to the whole exercise of the police tasks (Mojanoski, 2011). From the research results can be seen tendencies that there is a lack of willingness of citizens for timely reporting to the police, especially in cases of detecting anything suspicious in their neighborhood, while providing necessary information to the police and willingness to testify in court, and taking measures for personal reliability and security of their property, especially for participation in programs and activities to improve safety, protect the citizens themselves in the youth and children. We should mention that it is the resultant reduction of the concept of community policing media project in which certain institutions, as well as senior managers in police appear in the role of "charity" and teach foreigners or citizens of the dangers of certain activities. In that sense, no lag and various councils and other bodies whose task is to develop relationships and establish partnerships with institutions and individuals tasked with safety concerns and unimpeded life in the community. This means that the activities are directed towards the prevention and suppression of crime on the provision of the public order and peace. Despite the undeniable importance of such achievements and resources, the citizens are the main actors of the prevention of crime, and an important factor in the cognition about committed crimes, and often in their disclosure (Milosavljević, 1992).

\section{Conclusion}

The so far analysis shows that in the perceptions of the citizens dominate certain attitudes attitudes which more or less mirror the social relations in the timeframe in which is conducted research. They are only an indicator of the notions and sections of the awareness in civility for the position and the relation of the police towards them. We need to keep in mind that on the formation of the public trust in the police has stakeholders who are not directly onto associated with the degree of integrity of the police towards the citizens. It especially affects the general conditions with corruption, but with the image of how it effectively performs the tasks in its combat, then the characteristics of the social structure, cultural traditions, the relationship of the citizens according to the norms, especially the law and the legal 
consciousness and a special capacity of the institutions of government and the manner of the exercise of their functions. All the listed factors influence on the attitude of the citizens towards the police and for their trust towards her.

The research results point to the fact that the police should set more concrete and realistic goals in terms of aspiration to gain the trust of the citizens, to win the favor of the public behind him and to the promotion of common interests: the better security of citizens and their property and fewer problems in the area of maintenance of public order and peace. In such cases, the critics of the public to the police or to the exercise of police functions in the society will be aimed at strengthening relations with the community. Police leadership and police are more oriented towards avoiding actions and behaviors that are typical of any democratic community.

\section{Bibliography}

1. Bayley, D. H. (1996). Police for the future. New York: Oxford University Press.

2. Bayley, D. H. (2006). Changing the Guard: Developing Democratic Police Abroad. New York: Oxford University Press, Inc.

3. Berkeley, G. (1969). The Democratic Policeman. Boston: Beacon Press.

4. Crank, J. P., Murray, R. K., Irlbeck, D. M., \& Sundermeier, M. T. (2011). MissionBased Policing. New York: CRC Press, Taylor \& Francis Group, LLC.

5. Damjanović, Mijat. (2002). Država, poredak vlast. Bo M. Damjanović, B. Raičević, G. Popov - Ilić, \& M. Damjanović (Уp.), Da li je socijalizam bio greška ? Politikološke teme (B. Robertson, Č. Robertson, \& J. Marić, Прев., стр. 119-132). Beograd: Magna Agenda.

6. Crabosky, P. (Ур.). (2009). Community Policing and Peacekeeping. New York: CRC Press Taylor \& Francis Group.

7. Ideološki i politički konflikti (Osvrt na kulturu dijaloga). (2011, April 11). Beograd. Преземено June 26, 2011 од http://www.scribd.com/doc/54575678/Ideoloski-i-Politicki-Konflikti-u-Srbiji2011-Osvrt-Na-Kulturu-Dijaloga-Fondacija-Centa-Za-Demokratiju.pdf

8. Maljević, A., Datzer, D., Muratbegović, E., \& Budimlić, M. (2006). Otvoreno 0 policiji i korupciji. Sarajevo: Udruženje diplomiranih kriminalista u Bosni i Hercegovini. 
9. Masleša, R. (1999). Policija organizacija i funkconiranje u demokratskom društvu. Sarajevo.

10. Masleša, R. (2001). Teorije i sistemi sigurnosti. Sarajevo: Magistrat.

11. Masleša, R. (2008). Policija i društvo. Priština: AAB univerzitet Priština. Преземено 05 01, 2017 од ttps://cerovic.files.wordpress.com/2014/02/policijai-drustvo-skripta.pdf

12. McNair, B. (2003). (2003): Uvod u političku komunikaciju, FPZ, Zagreb, str. 19. Zagreb: Fakultet političkih znanosti.

13. Merton, R. K. (1973). The Sociology of Scienc: Teoretical and Empirical Investigations. (N. W. Storer, Yp.) Chicago and London: The University of Chicago Press.

14. Mijalković, S. (2011). Nacionalna bezbednost (2 изд.). Beograd: Kriminalističkopolicijska akademija.

15. Milosavljević, B. (1992). Nauka o policiji. Beograd: Policijska akademija.

16. Mirosavljević, M. (2006). Odnosi s javnošću. Banja Luka: BLC Beseda, Fridrih Ebert Shtiftung. Преземено 10 4, 2012 од library.fes.de/pdffiles/bueros/.../06282.pdf

17. Mitrović, L., \& Pavlović, G. (2012). Sistem bezbednosti Bosne i Hercegovine: pravno aspekti i aktuelno stanje. Banja Luka: Međunarodno udruženje naučnih radnika - AIS,

18. Modly, D., \& Korajčić, N. (2002). Kriminalistički rječnik,. Tešanj: Centar za kulturu i obrazovanje.

19. Wisle, D., \& Onwudiwe, I. D. (Yp.). (2009). Community Policing - International Patterns and Comparative Perspectives. New York: CRC Press, Taylor \& Francis Group.

20. Zamir -Jonathan, T., Weisburd, D., \& Hasisi, B. (Уp.). (2016). Policing in Israel Studying Crime Control, Community Policing, and Counterterrorism. New York: CRC Press, Taylor \& Francis Group, LLC.

21. Zamir-Jonathan, T., Weisburd, D., \& Hasisi, B. (2014). Policing Terrorism, Crime Control, and Police-Community Relations - Learning from the Israeli Experience. New York: Springer.

22. Гаћиновић, Р. (2012). Модели организације савремених полицијских система. Култура полиса, IX(18), 229-249. Преземено 05 01, 2017 од http://kpolisa.com/KP18/kp18-V-1-RadoslavGacinovic.pdf 
23. Мојаноски, Ц. Т. (2011). Начелата на отчетност и јавност во работата на полицијата. (В. Ортаковски, Ур.) Годишник на Факултетот за безбедност Скопје, 210-223.

24. Мојаноски, Ц. Т. (2012). Методологија на безбедносните науки - Основи (Том Книга I). Скопје: Факултет за безбедност.

25. Мојаноски, Ц. Т. (2012). Методологија на безбедносните науки истражувачка постапка (Том Книга II). Скопје: Факултет за безбедност.

26. Мојаноски, Ц. Т. (2013). Методологија на безбедносните науки - аналитички постапки, Книга III. Скопје.

27. Мојаноски, Ц. Т. (2015). Методологија на безбедноите науки - основи, Книга I (2 изд.). Скопје: Факултет за безбедност - Скопје.

28. Мојаноски, Ц. Т. (2015). Методологија на безбедноните науки - истражувачка постапка, Книга III (2 изд.). Скопје: Коста Абраш - Охрид.

29. Стојановски, Т. (1997). Полицијата во демократското општество. Штип, Скопје: 2 Авгус С \& ДОО Астор. 